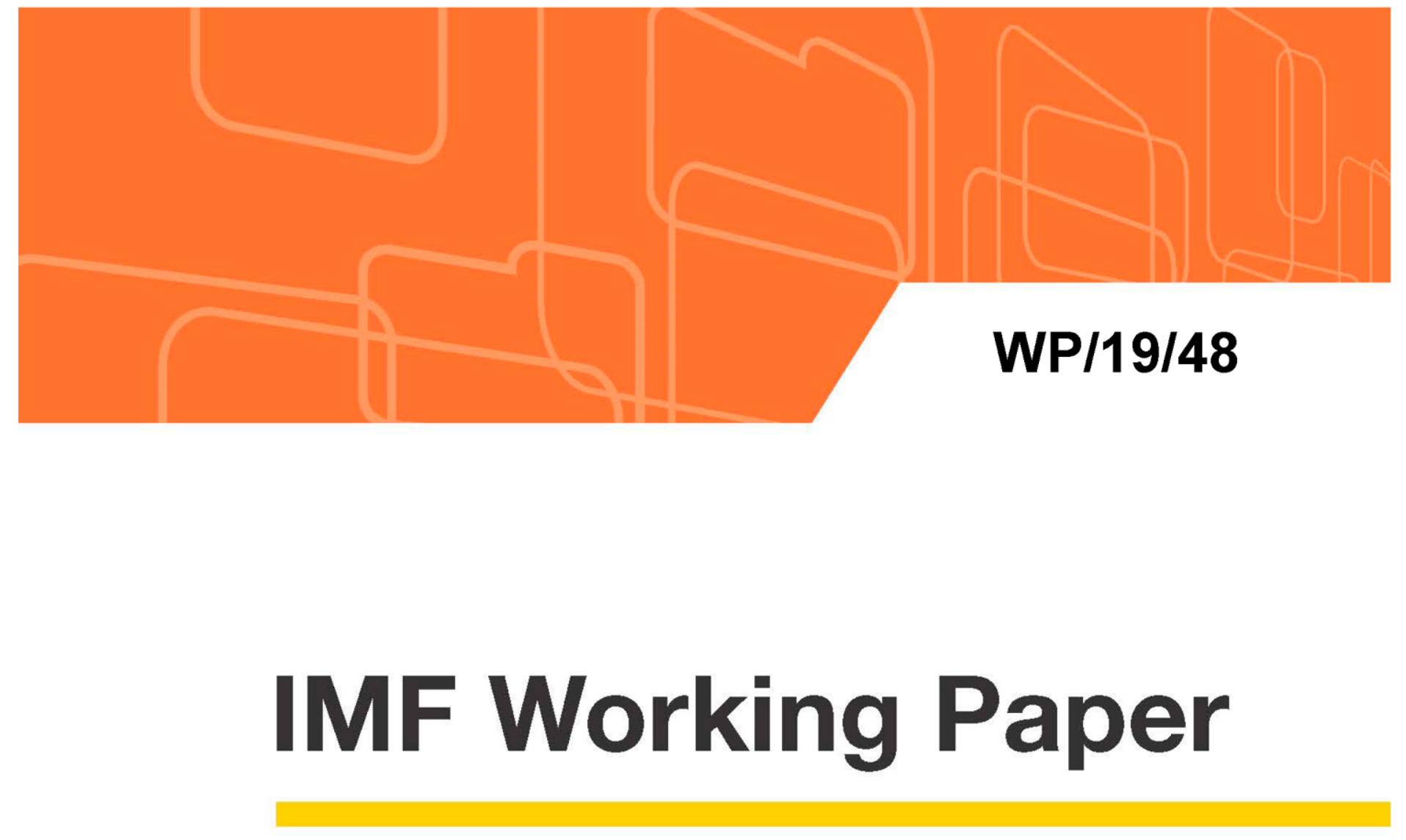

\title{
Nonlinearity Between the Shadow Economy and Level of Development
}

by Dong Frank Wu and Friedrich Schneider

IMF Working Papers describe research in progress by the author(s) and are published to elicit comments and to encourage debate. The views expressed in IMF Working Papers are those of the author(s) and do not necessarily represent the views of the IMF, its Executive Board, or IMF management. 


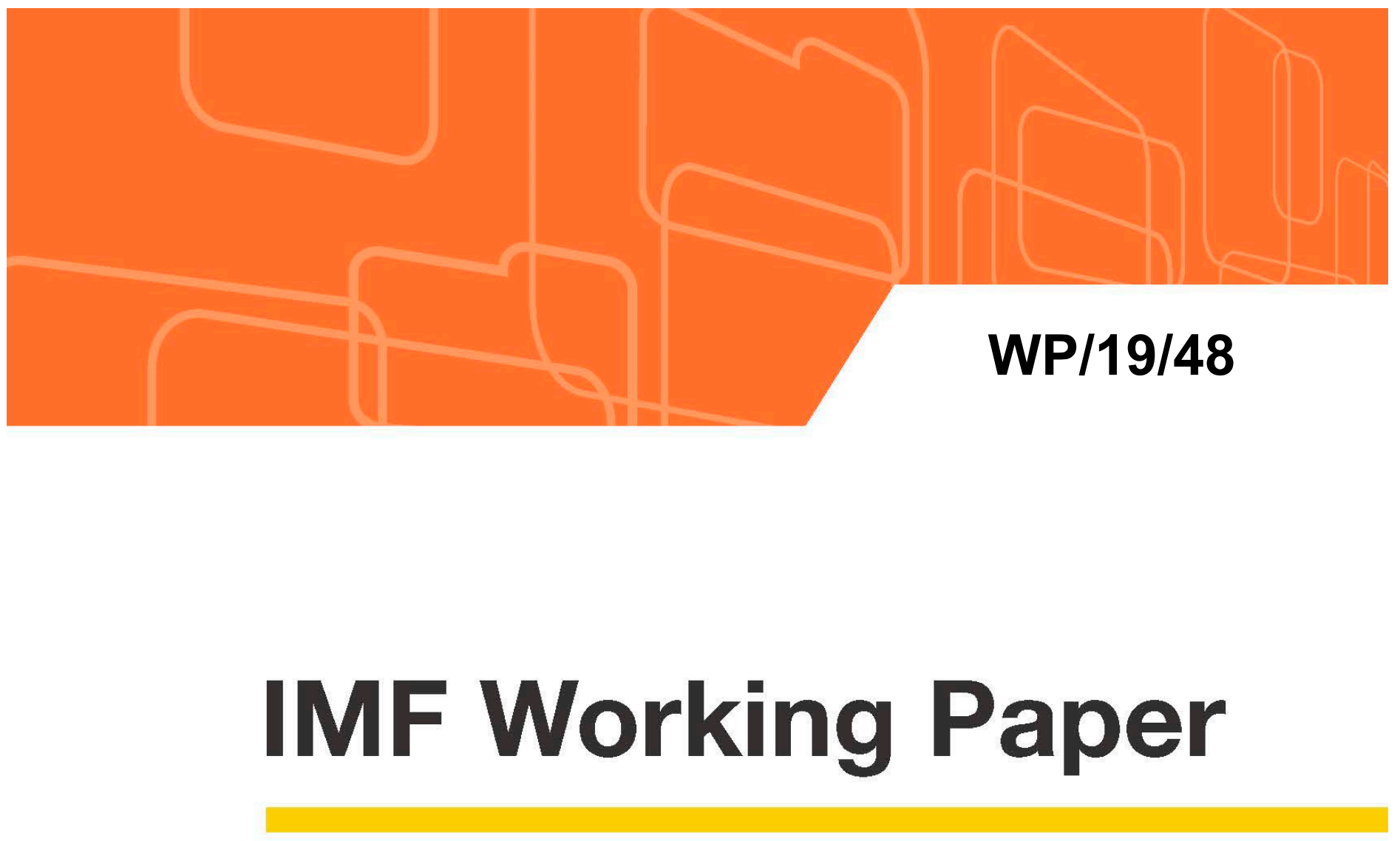

\section{Nonlinearity Between the Shadow Economy and Level of Development}

by Dong Frank Wu and Friedrich Schneider

IMF Working Papers describe research in progress by the author(s) and are published to elicit comments and to encourage debate. The views expressed in IMF Working Papers are those of the author(s) and do not necessarily represent the views of the IMF, its Executive Board, or IMF management.
I N
N T E R
R N A T I O N A L
$M O N E T A R$ T
F U N D 


\title{
IMF Working Paper
}

Institute for Capacity Development

\section{Nonlinearity Between the Shadow Economy and Level of Development* Prepared by Dong Frank $\mathrm{Wu}^{\ddagger}$ and Friedrich Schneiders}

Authorized for distribution by Laura Kodres

March 2019

\begin{abstract}
IMF Working Papers describe research in progress by the author(s) and are published to elicit comments and to encourage debate. The views expressed in IMF Working Papers are those of the author(s) and do not necessarily represent the views of the IMF, its Executive Board, or IMF management.
\end{abstract}

\begin{abstract}
This paper is the first attempt to directly explore the long-run nonlinear relationship between the shadow economy and level of development. Using a dataset of 158 countries over the period from 1996 to 2015, our results reveal a robust U-shaped relationship between the shadow economy size and GDP per capita. Our results imply that the shadow economy tends to increase when economic development surpasses a given threshold or at least does not disappear. Our findings suggest that special attention should be given to the country's level of development when designing policies to tackle issues related to the shadow economy.
\end{abstract}

JEL Classification Numbers: E26, H26, O17, O43, I25

Keywords: Shadow Economy, Level of Development, Nonlinearity, GDP per capita

Author’s E-Mail Address: dwu@imf.org, friedrich.schneider@jku.at

\footnotetext{
${ }^{*}$ We are grateful to Laura Kodres, Ashique Habib, Futoshi Narita, Claudia Berg and other colleagues for their valuable comments and suggestions during the review process. We'd like to thank Leandro Medina and Ceyhun Elgin for sharing their estimated datasets. All remaining errors are ours. The views expressed herein are those of the authors and should not be attributed to the IMF, its Executive Board, or its management.

* Corresponding Author, IMF, Washington D.C.

$\S$ Retired Professor, University of Linz, Finance Institute, Linz, Austria.
} 


\section{CONTENTS}

\begin{tabular}{|c|c|}
\hline ABSTRACT & $-\underline{1}$ \\
\hline I. INTRODUCTION & $-\underline{3}$ \\
\hline II. LITERATURE REVIEW & $-\underline{5}$ \\
\hline III. METHODOLOGY AND DATA & $\underline{7}$ \\
\hline 3.1 Empirical methodology & -1 \\
\hline 3.2 Data & $\underline{8}$ \\
\hline IV. EMPIRICAL RESULTS & $\underline{10}$ \\
\hline 4.1 Findings of the benchmark model & $\underline{10}$ \\
\hline 4.2 Further investigation of non-linear relationship & 11 \\
\hline 4.3 Robustness check & $\underline{13}$ \\
\hline 4.3.1 Robustness check by controlling for tax burden and for country groups & 13 \\
\hline 4.3.2 Robustness check with 10 -year averages & $\underline{15}$ \\
\hline 4.3.3 Robustness check with 5-year averages & $\underline{16}$ \\
\hline 4.3.4 Robustness check by controlling for the four oil-exporting countries & $\underline{18}$ \\
\hline 4.4 More Discussions on Labor Market and Policy Implications & $\underline{19}$ \\
\hline V.CONCLUSION & $\underline{22}$ \\
\hline REFERENCES & $\underline{23}$ \\
\hline APPENDIX & $\underline{25}$ \\
\hline
\end{tabular}

\section{FIGURES}

Figure 1: Nonlinear relationship between the shadow economy and GDP per capita

Figure 2: Nonlinear relationship between the shadow economy and GDP per capita in 2010 US\$_ 18

\section{TABLES}

Table 1: Nonlinearity between the shadow economy and GDP per capita: average of 1996-2015 -11

Table 2: Long-run determinants of GDP per capita: average of 1996-2015

Table 3: Robustness check I

Table 4: Robustness check II

Table 5: Robustness check III

Table 6: Robustness check IV: panel regression

Table 7: Robustness check V: panel regression with one-period lags

Table 8: Robustness check VI: panel regression with two-period lags

Table 9: Robustness check VII: the average of 1996-2015

Table 10: Robustness check VIII: the average of 1996-2015

Table A1: Country names and ISOs

Table A2: Table of correlations of variables for 1996-2015

Table A3: Summary statistics of variables for 1996-2015

Table A4: Analytical categorization of the global economy 


\section{INTRODUCTION}

The shadow economy has been labelled with many names, such as the informal economy, hidden economy, black economy or underground economy. Although existing studies provide a broad range of definitions or descriptions of the shadow economy, most of them are similar. This paper follows the definition proposed by Medina and Schneider (2018) since their estimated data is used for the size of the shadow economy: "...The shadow economy includes all economic activities which are hidden from official authorities for monetary, regulatory, and institutional reasons. Monetary reasons include avoiding paying taxes and all social security contributions, regulatory reasons include avoiding governmental bureaucracy or the burden of regulatory framework, while institutional reasons include corruption law, the quality of political institutions and weak rule of law. For our study, the shadow economy reflects mostly legal economic and productive activities that, if recorded, would contribute to national GDP...."

One of the intensively studied topics in economics is the causes of the shadow economy (SE) around the world. Although our understanding of the potential shadow economy drivers has improved substantially in the past two decades ${ }^{1}$, questions regarding its long-run behavioral pattern are still open to debate. For example, does the size of the shadow economy converge to a certain level, or does it have a robust long-run linear relationship with its determinants? This paper aims to fill the gap in the literature by investigating the long-run relationship between the shadow economy and its key determinants.

The paper identifies a U-shaped relationship between the size of the shadow economy ${ }^{2}$ and the level of economic development, using a panel dataset covering 158 countries from 1996 to 2015. We take into account a wide range of the shadow economy's determinants and adopt various regression specifications to test the robustness of the nonlinearity between the shadow economy and GDP per capita. ${ }^{3}$ Our results reveal that, after controlling for key economic, policy, and institutional variables, the economies at a low development level witness a negative relationship between the size of the shadow economy and GDP per capita, but when GDP per capita exceeds a threshold, the size of the shadow economy goes up with per capita income. These findings are consistent with economic intuition that economic development may have two opposite impacts on the size of the shadow economy. On the one hand, economic development, characterized by productivity improvement and technology advance, may support the long-run expansion of the shadow economy because a high level of development means a high level of human capital, which

\footnotetext{
${ }^{1}$ See Schneider and Enste (2000), La Porta and Shleifer (2008), Feld and Schneider (2010), Schneider (2017), and Williams and Schneider (2016).

${ }^{2}$ In the paper, the size of the shadow economy is expressed as the percentage ratio of the shadow economy to official GDP.

${ }^{3}$ The paper uses GDP per capita as proxy for the level of economic development.
} 
helps individuals to make a living relatively easy. When less constrained by financial pressures, people prefer informal jobs to gain more work flexibility or to reach a better life-work balance, especially if there is a catch-up in the wage difference between the formal and informal sectors. In addition, technology innovation can support the growing trend of the shadow economy by providing more convenient jobs and reliable decentralized payment systems. ${ }^{4}$ On the other hand, economic development can help downsize the shadow economy by offering high quality public goods and services. High level of economic development is normally featured by stronger institution capacity and better social infrastructure, all of which help absorb firms and individuals from the informal sector or encourage them to stay formal. The two competing forces jointly determine the net effect of economic development on the shadow economy: at a low level, the downsizing effect associated with economic development plays a dominate role, people join or switch to the formal sector to enjoy more benefits of economic growth, and thus the shadow economy shrinks; at a high level, more household members obtain financial freedom to an extent that they are willing consider informal jobs to pursue diverse goals and thus there is a gradual resurgence of the informal sector.

The U-shaped curve 5 , as Figure 1 displays, discloses a different development pattern from most of existing studies which assume or identify a linear relationship between the size of the shadow economy and its determinants. The non-linearity finding implies that the shadow economy is able to co-exist with different levels of development and the shadow economy does not disappear in the long run. This is contrary to the inference of a linear relationship which predicts a shrinking trend or final disappearance of the shadow economy. One question from Figure 1 is related to the observation that GDP per capita of most countries lies at the downward part of the U-shaped curve while only a few on the other part especially including four oil-exporting countries. ${ }^{6}$ The paper examines the robustness of the relationship by dropping the four countries.

The paper also seeks to identify the potential factors which boost GDP per capita. Consistent with the growth literature, we find that educational attainment plays a vital role in improving GDP per capita, especially a college degree or above. This result helps shed some light on a possible mechanism of a U-shaped pattern at the micro level. From the individual perspective, people work to make themselves better off. When the level of development is low, education helps build up labor productivity and skilled workers with college education or above choose to stay in the formal sector to enjoy benefits from high productivity position and social security net. When the economy advances to a new level at which income of skilled workers becomes high enough and one household member can easily cover the whole family's daily expenses, demand for informal work

\footnotetext{
${ }^{4}$ Going forward, new waves of the digital economy, data sharing, and the gig economy are expected to play a key role in boosting the shadow economy. Also, blockchain technology and cryptocurrencies can be utilized to pay workers in the informal sector.

${ }^{5}$ The following sections examine the nonlinearity with rigorous econometric methods. In addition, the non-linear relationship may not necessarily be symmetric around the turning point. We leave the investigation of the asymmetric nonlinearity to future research.

${ }^{6}$ They are Brunel, United Arab Emirates, Kuwait, and Qatar (as BRN, ARE, KWT and QAT in Figure 1).
} 
is likely to increase due to work flexibility or other desirable perks. Hence the size of shadow economy reverses its downtrend.

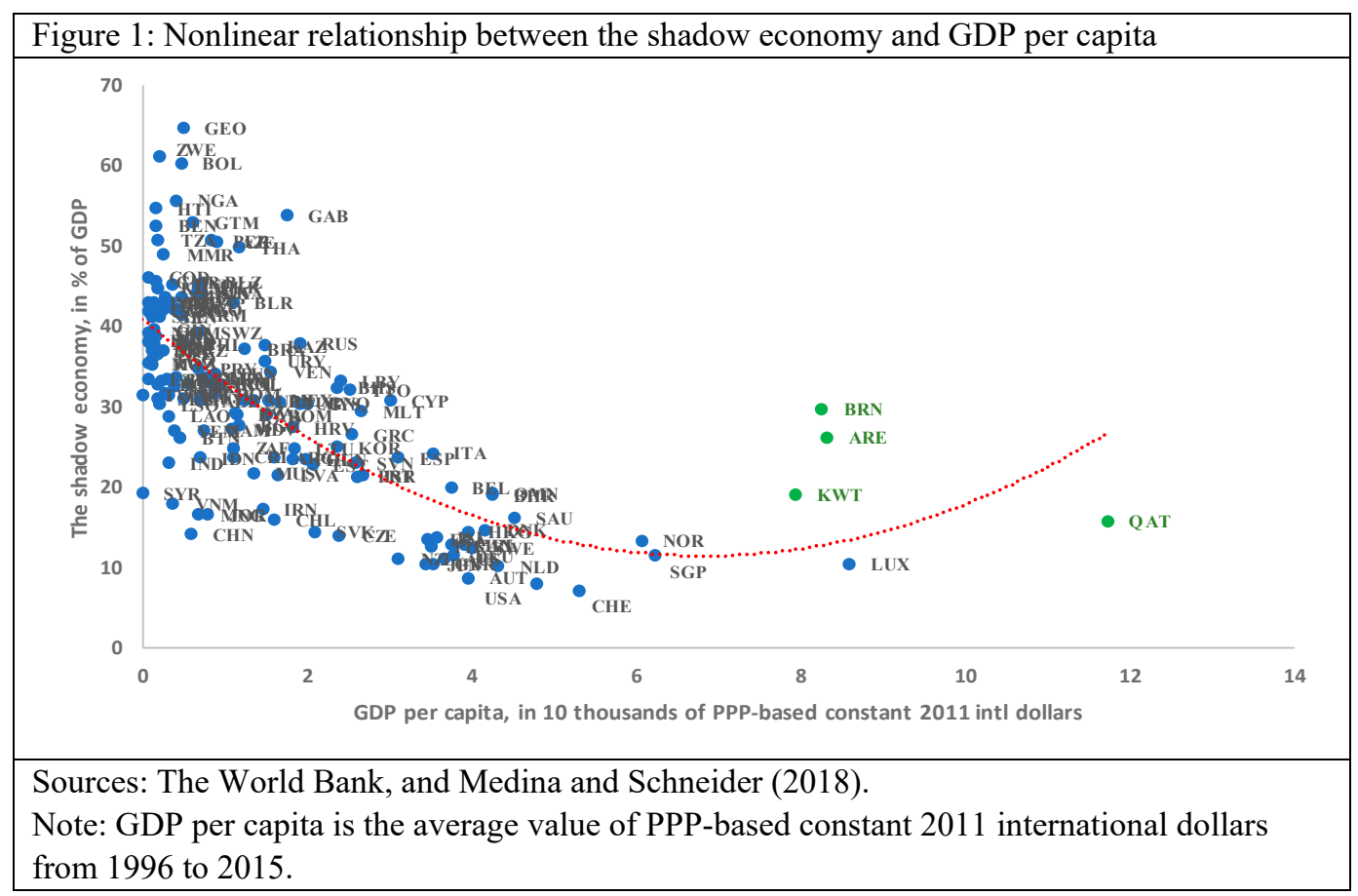

The rest of the paper is organized as follows: Section II reviews the literature on the shadow economy and highlights the paper's contribution; Section III explains the methodology and the dataset; Section IV presents the empirical results and conducts robustness checks; and Section V concludes.

\section{LITERATURE REVIEW}

There has been a considerable amount of economic research studying the shadow economy or the informal economy, particularly with a focus on its estimated size and causes. ${ }^{7}$ The estimation approaches include survey-based methods, observable-variable methods and model-based

\footnotetext{
${ }^{7}$ A recent survey is by Elgin and Erturk (2018).
}

(continued...) 
methods. ${ }^{8}$ One of the latest examples is the paper by Medina and Schneider (2018) that uses the Multiple Indicators Multiple Causes (MIMIC) approach to find that the estimated average size of the shadow economy in 158 countries over 1991 to 2015 is 31.9 percent relative to GDP. The causes of the shadow economy can be categorized into three groups, namely economic, policyrelated, and regulatory and institutional factors. ${ }^{9}$ Among the key factors are access to financing, political stability, public services provision, tax burden, labor market regulations and institutional quality. Many papers identify the potential determinants of the shadow economy by assuming a simple linear impact while some take advantage of various interactions among the variables to revise or complement early findings. Almost all the papers, explicitly or implicitly, assume or agree that the shadow economy should be expected to shrink with economic growth, the upgrading in financial and public services, the improvement of institutional quality and regulatory effectiveness.

One related question is whether this shrinking trend of the shadow economy is a long-run irreversible phenomenon. Suppose that all the countries in the world keep making progress in strengthening their capacity in supervision and regulation, providing efficient public services, and effectively reducing their institutional weaknesses, then is it reasonable to predict that the shadow economy will continue shrinking until it disappears or become negligible?

The paper is the first attempt to investigate the non-linear long-run trend of the shadow economy and our major contribution includes the revelation of a U-shaped relationship between the shadow economy and the level of development. This paper uses GDP per capita to serve as proxy for the level of development. Although some papers already use GDP per capita in their studies, their purposes are to control for the level of development (La Porta and Shleifer, 2008). We allow for a U-shaped relationship by including squared GDP per capita. Our main results disclose the significance of the squared GDP per capita term, and the following regressions support its robustness.

Furthermore, this paper explores the possible long-run factors for the level of development and it is not surprising to find that educational attainment plays a vital role, especially college degrees and above. However, our finding regarding this variable contrasts with earlier work. Buehn and Farzanegan (2013) find that higher education levels can decrease the shadow economy in a strong institution environment by interacting education and institutional quality in their regression model. Their finding suggests that the sign of the educational impact on informality depends on the institutional quality. When the quality of institutions is high enough, their model implies that improved educational achievement contributes to the decline of the shadow economy. The issue with their work is the estimated effect of institutional quality on the shadow economy. As their

\footnotetext{
${ }^{8}$ See Medina and Schneider (2018) for detailed discussion, as well as Gerxhani (2003), Kirchgaessner (2016) and Adair (2016).

${ }^{9}$ See Schneider (2014, 2017), La Porta and Shleifer (2008, 2014), and Williams and Schneider (2016) for details. Regarding the role of the shadow economy on the economic development, see the dual view proposed by Lewis (1954) and advocated by La Porta and Shleifer (2008), La Porta and Shleifer (2014), Feld and Larsen (2009), and Feld and Schneider (2010).
} 
paper shows, the institution has an overall positive impact on the size of the shadow economy and the impact declines with education level due to the same interaction item mentioned above, which contradicts with economic intuition and is hard to explain. In addition, this paper's finding is contrary to Elgin and Erturk (2016) that support the negative relationship. The regression in Elgin and Erturk (2016) uses a longer time series on the size of shadow economy while it relies on only fixed effect dummies to control for all other factors. In addition, Elgin and Erturk (2016) set up a model to capture the underlying mechanism in which it assumes the value of TFP is constant. Instead, their model implies the size of the shadow economy depends on the relative TFP values between the formal and informal sectors. If there is a catch up from the informal sector productivity, its size tends to increase, which is consistent with our paper's finding.

This paper focuses on the long-term determinants of the size of the shadow economy while Elgin and Birinci (2016) explores the nonlinear impact of the shadow economy on economic growth. The first difference of these two papers is the direction of the impact as Elgin and Birinci (2016) aims to identify one new factor of growth. Second, there is no direct inference between the two papers findings. Elgin and Birinci (2016) finds the inverted-U between the shadow economy and growth of GDP per capita. Given that growth of GDP per capita has no simple monotone relationship with the level of GDP per capita, it is hard to derive from their findings a relationship between the shadow economy and GDP per capita and thus to judge whether our paper is consistent with theirs or not. Though, one key finding of Elgin and Birinci (2016) is that the informal sector has positive spillover effects on TFP growth. If one major source of TFP growth is research and development activities, how can we reconcile their finding with existing empirical ones or what aspect of the informal economic activities is instrumental to TFP growth?

\section{MeThOdOLOGY AND DATA}

In this section, we set up a framework for the comprehensive econometric analysis to identify the nonlinear relationship between the size of the informal economy and GDP per capita.

\subsection{Empirical methodology}

We conduct several regressions with different estimators. The benchmark cross-sectional regression is based on the following setting:

$$
S E_{i}=\beta_{0}+\beta_{1} y_{i}+\beta_{2} y_{i}^{2}+\sum_{k=3}^{n} \beta_{k} x_{k, i}+\varepsilon_{i}
$$


where $S E_{i}$ is the percentage ratio of the shadow (or informal) economy relative to GDP of country $i ; y_{i}$ stands for GDP per capita for country $i ; x_{k, i}$ represents other control variables; and $\varepsilon_{i}$ denotes the error term. The inclusion of the squared GDP per capita term in the regression is to check the potential existence of a nonlinear relationship between the size of the informal economy and GDP per capita.

In the subsequent parts, we first do the cross-sectional regression using variables constructed as 20-year averages. Then, the robustness check is conducted with various settings: (i) dummy variables are used to control for country group effects which is complemented by separate regressions on each country group; (ii) regressions on variables of 10-year average are conducted to further confirm the original findings; (iii) the panel regression method with 5-year average is adopted to continue checking the validity of the empirical results, which includes regressions with one-period lagged variable to control for endogeneity; (iv) regressions to control for other potential economic and institutional factors.

For the panel regression, the equation is set up as follows:

$S E_{i t}=\beta_{0}+\beta_{1} y_{i t}+\beta_{2} y_{i t}^{2}+\sum_{k=3}^{n} \beta_{k} x_{k, i t}+\theta_{i}+\delta_{t}+\varepsilon_{i t}$

where dummies of $\theta_{i}$ and $\delta_{t}$ are inserted to reflect the country and time effects. Both the fixedeffect and random-effect estimators are reported in the paper.

\subsection{Data}

Our paper collects the annual cross-country panel data covering 158 countries or regions from 1996 to $2015 .{ }^{10}$ In our regressions, the variables are 20-year, 10-year or 5-year averages. Variables constructed as 20-year and 10-year averages are used in the cross-sectional regressions and the 5year average variables are fed into the panel data regressions.

The size of the shadow economy relative to GDP is borrowed from Medina and Schneider (2018), which revise the standard MIMC approach by using light intensity instead of GDP as an indicator variable. By limiting GDP only as a cause variable, this revision helps improve the estimation results. To make the paper's findings reliable, the paper also uses the shadow economy data from Elgin and Oztunali (2012) ${ }^{11}$ as a robustness check. Elgin and Oztunali (2012) estimates the shadow

\footnotetext{
${ }^{10}$ Most of the key time series are from 1990 to 2015 except for the World Governance Index which starts from 1996. Therefore, our regressions change the sample period to the range of 1996 to 2015.

${ }^{11}$ The estimated size of the shadow economy from Elgin and Oztunali (2012) spans from 1950 to 2014.
} 
economy based on a deterministic dynamic general equilibrium model. As Table A2 in the Appendix shows, the two estimated series are quite correlated with each other.

The choice of control variables is based on the existing empirical literature, including GDP per capita, political stability index, growth of GDP per capita, CPI inflation, trade openness, financial depth, tax burden, education-related variables, and capital stock. Detailed information about these variables is below:

- GDP per capita comes from the World Development Indicators (WDI) database and two measurements are used to ensure the robustness of the results: one is PPP-based constant 2011 international dollars and the other is constant 2010 US dollars. This latter series is the main series used to establish the paper's major finding.

- To control for institutional differences, the index of political stability is extracted from the database of the World Governance Indicators (WGI). Its original values range from -2.5 to 2.5 which the paper changes into 0 to 100 .

- The non-institutional variables of GDP per capita growth, CPI inflation, trade openness, financial depth and tax burden are also from the WDI. GDP per capita growth is calculated with national currency and the lowest GDP per capita growth occurs in Libya in 2011. Inflation is measured with CPI data and expressed in percent. Trade openness is defined as the sum of exports and imports of goods and services as a percentage of GDP. Financial depth is measured as domestic credit to private sector provided by financial corporations ${ }^{12}$, such as through loans, nonequity securities and trade credit. Tax burden is captured by the ratio of taxes and mandatory contributions payable to commercial profits.

- The regression, aiming to explore the determinants of GDP per capita, also uses data on educational attainment from the WDI and total capital stock from the IMF. Three educational variables are constructed: the percentages of people completing primary school only, completing high school only, and completing college and above. ${ }^{13}$ The IMF Investment and Capital Stock Dataset (ICSD) includes three measurements of capital stock, namely public capital, private capital and public-private-partnership (PPP) capital. The paper calculates the total capital stock as the sum of the three time series.

\footnotetext{
${ }^{12}$ Financial corporations include monetary authorities, deposit money banks and other financial corporations like finance and leasing companies and insurance corporations.

${ }^{13}$ Please note that for most countries, data on completing high school or above is available only after 2012 . This is why the number of observations for high-school-or-above education attainment is so small compared with that of the primary school attainment.
} 


\section{EMPIRICAL RESULTS}

This section presents the empirical findings on the nonlinear interaction between the shadow economy and GDP per capita.

In this paper, endogeneity can come from two main possible sources: (i) the impact of the informal activities on the formal sector, via households' or firms' decisions, may imply that institution and economic variables on the right side of the regression equation may be influenced by the size of the shadow economy ${ }^{14}$; (ii) the measurement error embedded in the estimated size of the shadow economy may also lead to the two-way causality between regressors and dependent variables. The paper adopted various specifications to check the sensitivity of the results and to ensure that endogeneity has been effectively mitigated.

\subsection{Findings of the benchmark model}

The results of the benchmark static cross-sectional regression are reported in Table 1, which uses each country as one observation by taking a 20 -year average on all relevant time series.

The first column reports the regression results using the estimated shadow economy size from Medina and Schneider (2018) and GDP per capita in PPP-based international dollars, while the second column reports the regression on GDP per capita in 2010-based US dollars. The third column reports the results of regressing the estimated informality numbers from Elgin and Oztunali (2012) on PPP-based GDP per capita. All three regressions identify, at the 1-percent significance level, the positive coefficient for the squared shadow economy size and thus support the existence of the U-shaped relationship between the shadow economy and GDP per capita. That is, the shadow economy shrinks with the increase of GDP per capita until it reaches a threshold; after that point, the shadow economy and GDP per capita are positively related and the shadow economy size grows with GDP per capita.

The benchmark regression uses the indicator of political stability from the WGI to proxy for institutional factors, which is motivated by Elbahnasawy et al (2016). The coefficient for political stability is consistantly negative, implying that institutional factors help contain the expansion of the shadow economy.

\footnotetext{
${ }^{14}$ See Table A2 of the correlation matrix.
} 
In addition, the estimated negative coefficient of financial depth reveals that financial development is instrumental in dampening the activities of the shadow economy, which is consistent with the findings of World Bank Enterprise Surveys. ${ }^{15}$

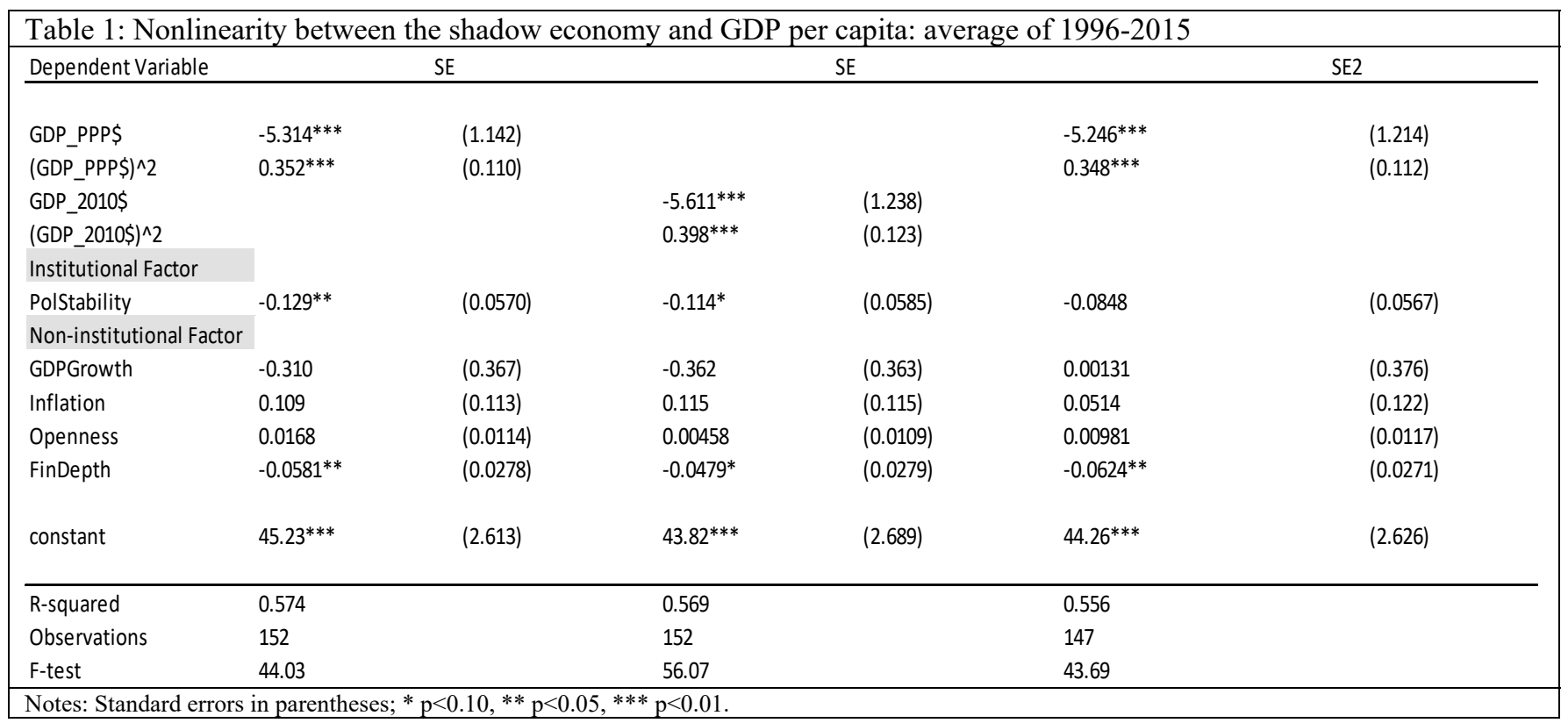

\subsection{Further investigation of non-linear relationship}

What factors determine the long-run value of GDP per capita and thus indirectly influence the size of the shadow economy? The classic production function implies that physical capital, human capital and technology are three fundamental variables. In addition, Barro (2013) argues that inflation is negatively related to economic growth. Guided by the existing literature, the regression equation of GDP per capita is set as following:

$y_{i}=\beta_{0}+\beta_{1} *$ college $_{i}+\beta_{2} *$ HighSch $+\beta_{3} *$ PrimSch $+\beta_{4} *$ inflation $+\beta_{5} *$ CapStock $+\varepsilon_{i}$

Results in Table 2 reveal that educational attainment contributes to the increase of GDP per capita, especially college and graduate degrees. It is not surprising to see that a bachelor degree and above are significant and more important than high school and primary school in boosting GDP per capita. College and post-graduate education helps employees to reach higher productivity and the skill-complementary technology trend in recent decades has created a constant demand for skilled

\footnotetext{
${ }^{15}$ La Porta and Shleifer (2014) highlight the role of financial access, one important aspect of financial development. They compare perceived obstacles to doing business reported by informal and formal entrepreneurs and list access to financing as the top 1 factor for firm-owners to make decisions of whether to stay formal or not.
} 
labor as Acemoglu (2002) shows. In addition, the regression confirms that inflation is detrimental to GDP per capita, supporting existing studies on the long-run negative relationship between inflation and economic growth.

Then, what is the economic intuition behind the implied long-run relationship between education and the shadow economy? The formal sector is more productive than the informal sector and firms tend to move out of the informal sector to hire skilled workers when more people become welleducated, thus reducing the size of the shadow economy. However, when education attainment reaches a certain level as GDP per capita hits a threshold, further increases in education attainment not only pushes up GDP per capita but also reverses the declining trend of the shadow economy. This reversal could be attributed to the increase in the informal sector's salary due to the growing productivity level. When household revenue exceeds a critical level, financial pressure becomes less intense. Some family members may become more willing to take temporary unregistered assignments than formal full-time or part-time positions in exchange for flexibility, which leads to the expansion of the shadow economy.

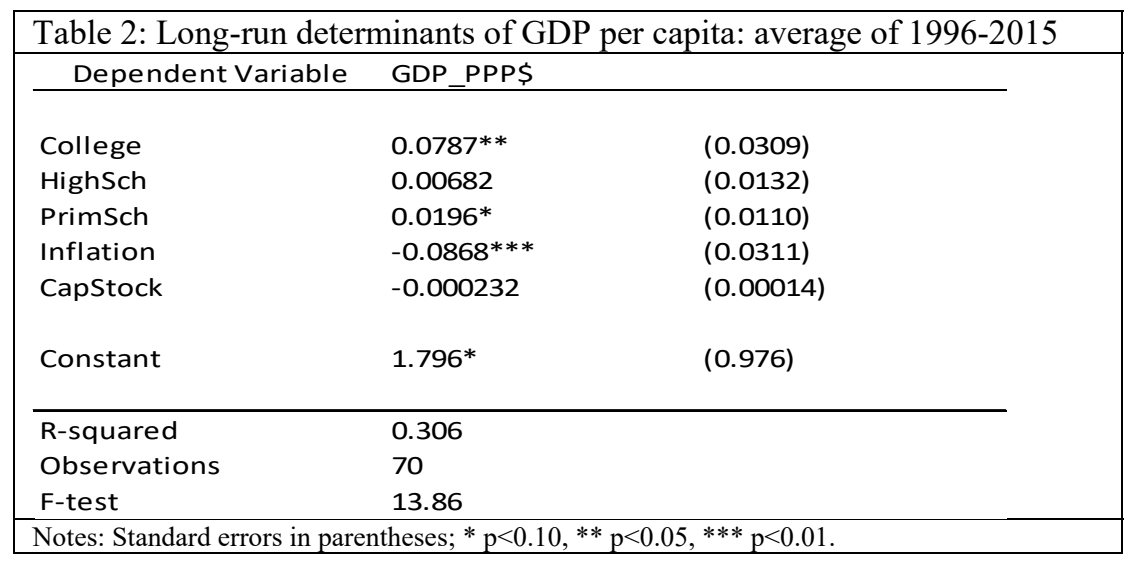

It is worth noting that the R-squared value indicates that education, capital stock and inflation can explain about 30.6 percent of the level of GDP per capita and a large share of GDP per capita remains unexplained in the regression. In addition, capital stock's impact on GDP per capita is not significantly different from zero in the long run. 


\subsection{Robustness check}

Besides the initial robustness regressions in Table 1, this sub-section continues to conduct robustness checks to test the observed U-shaped relationship between the shadow economy and GDP per capita. Specifically, we implement four types of tests. First, this sub-section explores the robustness of the U-shaped relationship with an additional control variable, tax burden, and then within different country groups, which includes regressions with country group dummies and separate estimations for each country group. Second, the paper uses 10-year averages to run the benchmark regression to check the results' consistency. Third, the paper calculates 5-year averages and runs panel regressions with different estimators to check if the same relationship exists. Lastly, the section tests the robustness of the result by dropping the four oil-exporting countries on the upward part of the U curve.

\subsubsection{Robustness check by controlling for tax burden and for country groups}

This subsection investigates the robustness of our results by controlling for tax burden and for different country groups. One motivation for firms to remain unregistered and in the informal sector is to avoid taxes. ${ }^{16}$ A potential question is whether, in the long-run and at the national level, the tax burden is a factor in affecting a firm's decision to stay formal or whether it has any implication for the long-run nonlinearity. In the regression, we add the ratio of corporate tax to corporate profit as proxy for a firm's tax burden. The first column of Table 3 shows a positive but insignificant coefficient for the tax variable while the two GDP-per-capita variables remain significant.

It is interesting to check if the nonlinear relationship significantly exists within different country groups. To achieve this goal, the paper divides the countries with two criteria. The paper borrows the definition of advanced economy (AE) from IMF (2017) and splits the 158 countries into AEs and non-AEs. The paper also follows the World Bank's classification, using 2015 gross national income (GNI) per capita, to group all countries or regions into three categories: low-income countries (LICs) with annual income below \$1,025; middle-income countries (MILs) with annual income from $\$ 1,026$ to $\$ 12,475$; and high-income countries (HILs) with income of $\$ 12,476$ or more. $^{17}$

\footnotetext{
${ }^{16}$ Recent research provides empirical and quantitative evidence to support the negative correlation between taxes and the informal sector and attributes it to high quality institutional factors (Friedman et al., 2000) or public turnover and public trust in government (Elgin and Solis-Garcia, 2012). The appearance of the negative correlation is likely due to the failure of the analysis to identify or control for other important determinants.

${ }^{17}$ See Appendix for the country list of each group.
} 


\begin{tabular}{|c|c|c|c|}
\hline \multirow[t]{2}{*}{ Dependent Variable } & SE & SE & SE \\
\hline & With tax burden & With dummy for AEs & With dummies for HICs and LICS \\
\hline GDP_PPP\$ & $-5.301^{* * *}(1.143)$ & $-4.562^{* * *}(1.181)$ & $-3.769^{* *}(1.474)$ \\
\hline$\left(G D P \_P P P \$\right)^{\wedge} 2$ & $0.352^{* * *}(0.110)$ & $0.286^{* *}(0.111)$ & $0.239 *(0.125)$ \\
\hline \multicolumn{4}{|l|}{ Institutional Factor } \\
\hline PolStability & $-0.129^{* *}(0.0571)$ & $-0.112 *(0.0574)$ & $-0.111^{*}(0.0591)$ \\
\hline \multicolumn{4}{|c|}{ Non-institutional Factor } \\
\hline GDPGrowth & $-0.301(0.372)$ & $-0.271(0.377)$ & $-0.270(0.357)$ \\
\hline Inflation & $0.109(0.113)$ & $0.103(0.115)$ & $0.0985(0.118)$ \\
\hline Openness & $0.0172(0.0114)$ & $0.0149(0.0117)$ & $0.0156(0.0119)$ \\
\hline FinDepth & $-0.0577^{* *}(0.0281)$ & $-0.0439(0.0303)$ & $-0.0546 *(0.0277)$ \\
\hline TaxBurden & $0.00461(0.0184)$ & $0.0107(0.0186)$ & $-0.000863(0.0200)$ \\
\hline \multicolumn{4}{|l|}{ Dummy } \\
\hline $\mathrm{AE}$ & & $-3.987^{*}(2.251)$ & \\
\hline $\mathrm{HIC}$ & & & $-3.749(2.867)$ \\
\hline LIC & & & $2.123(2.144)$ \\
\hline Constant & $44.91^{* * *}(3.062)$ & $43.39 * * *(3.112)$ & $43.31^{* * *}(3.297)$ \\
\hline R-squared & 0.574 & 0.581 & 0.580 \\
\hline Observations & 152 & 152 & 152 \\
\hline F-test & 39.33 & 38.50 & 32.17 \\
\hline
\end{tabular}

The second and third columns of Table 3 presents the regression results with country group dummies. One advantage of this method is to utilize all the observations instead of regressing on a subsample of the data. We can see the nonlinear relationship remains significant even with the dummies. To further investigate the robustness of the U-shaped relationship for each country group, the paper runs separate regressions for country groups of AEs, non-AEs, HICs and nonHICs. Table 4 shows that the squared GDP per capita remains significant for AEs, non-AEs and HICs. In contrast, non-HICs demonstrate a significant linear relationship between the shadow economy and GDP per capita. The negative linear relationship for non-HICs stems from the fact that almost all non-HICs lie far away from the threshold, where observations suggest a predominantly downward relationship.

The fact that the R-squared values for AEs and HICs are above 50 percent while those for nonAEs and non-HICs below 50 percent implies that nonlinearity is mainly driven by AEs or HICs whose GDP per capita lie around the threshold. 


\begin{tabular}{|c|c|c|c|c|c|}
\hline Dependent Variable & SE & SE & SE & SE & SE \\
\hline & For AEs & For non-AEs & For HICs & For non-HICs & For non-HICs \\
\hline GDP_PPP\$ & $\begin{array}{l}-8.954^{* * *} \\
(2.771)\end{array}$ & $\begin{array}{l}-4.081 * * * \\
(1.302)\end{array}$ & $\begin{array}{l}-6.728^{* * *} \\
(2.309)\end{array}$ & $\begin{array}{l}-4.549 \\
(5.626)\end{array}$ & $\begin{array}{l}-3.345^{*} \\
(1.773)\end{array}$ \\
\hline$($ GDP_PPP\$)^2 & $\begin{array}{l}0.555^{* *} \\
(0.224)\end{array}$ & $\begin{array}{l}0.249 * \\
(0.126)\end{array}$ & $\begin{array}{l}0.426^{* *} \\
(0.179)\end{array}$ & $\begin{array}{l}0.590 \\
(2.331)\end{array}$ & \\
\hline Institutional Factor & & & & & \\
\hline PolStability & $\begin{array}{l}-0.152^{*} \\
(0.0876)\end{array}$ & $\begin{array}{l}-0.0977 \\
(0.0651)\end{array}$ & $\begin{array}{l}-0.125 \\
(0.0865)\end{array}$ & $\begin{array}{l}-0.107 \\
(0.0774)\end{array}$ & $\begin{array}{l}-0.110 \\
(0.0737)\end{array}$ \\
\hline Non-institutional Fac & & & & & \\
\hline GDPGrowth & $\begin{array}{l}-1.938^{* *} \\
(0.936)\end{array}$ & $\begin{array}{l}-0.239 \\
(0.366)\end{array}$ & $\begin{array}{l}-2.589^{* * *} \\
(0.824)\end{array}$ & $\begin{array}{l}-0.194 \\
(0.421)\end{array}$ & $\begin{array}{l}-0.187 \\
(0.407)\end{array}$ \\
\hline Inflation & $\begin{array}{l}0.774 \\
(0.821)\end{array}$ & $\begin{array}{l}0.0764 \\
(0.121)\end{array}$ & $\begin{array}{l}1.151^{*} \\
(0.672)\end{array}$ & $\begin{array}{l}0.0680 \\
(0.139)\end{array}$ & $\begin{array}{l}0.0636 \\
(0.130)\end{array}$ \\
\hline Openness & $\begin{array}{l}0.0450^{* *} \\
(0.0171)\end{array}$ & $\begin{array}{l}0.0176 \\
(0.0182)\end{array}$ & $\begin{array}{l}0.0317^{* *} \\
(0.0127)\end{array}$ & $\begin{array}{l}0.0175 \\
(0.0256)\end{array}$ & $\begin{array}{l}0.0186 \\
(0.0254)\end{array}$ \\
\hline FinDepth & $\begin{array}{l}0.0258 \\
(0.0276)\end{array}$ & $\begin{array}{l}-0.0869 * * \\
(0.0428)\end{array}$ & $\begin{array}{l}-0.0234 \\
(0.0289)\end{array}$ & $\begin{array}{l}-0.0792 \\
(0.0563)\end{array}$ & $\begin{array}{l}-0.0829 \\
(0.0506)\end{array}$ \\
\hline Constant & $\begin{array}{l}45.65^{* * *} \\
(8.057)\end{array}$ & $\begin{array}{l}44.22^{* * *} \\
(2.867)\end{array}$ & $\begin{array}{l}45.11^{* * *} \\
(7.061)\end{array}$ & $\begin{array}{l}44.50^{* * *} \\
(3.016)\end{array}$ & $\begin{array}{l}44.32^{* * *} \\
(3.181)\end{array}$ \\
\hline R-squared & 0.623 & 0.310 & 0.517 & 0.155 & 0.155 \\
\hline Observations & 34 & 118 & 49 & 103 & 103 \\
\hline F-test & 5.202 & 10.80 & 9.271 & 2.988 & 3.500 \\
\hline
\end{tabular}

\subsubsection{Robustness check with 10-year averages}

In the previous subsections, all the regressions are conducted with variables of 20 -year averages to explore the long-run nonlinear relationship. One associated question is whether this nonlinear relationship remains unchanged if empirical analysis concentrates on shorter time horizons, such as a 10-year average or a 5-year average. This subsection conducts analysis based on two 10-year averages while the next one on four separate 5-year averages.

We run separate regressions for the periods of 1996-2005 and 2006-2015 and summarize the results in Table 5. Despite the changes in coefficient values between these two decades, the nonlinear relationship remains as expected, which indicates that the identified nonlinear 
relationship is stable in the medium term. This finding provides support to the results of the benchmark model.

\begin{tabular}{|c|c|c|c|c|}
\hline Dependent Variable & SE (10 year average of 1996-200 & & SE (10 year average of 2006-201 & \\
\hline GDP_PPP\$ & $-6.510^{* * *}$ & (1.358) & $-5.088^{* * *}$ & (1.062) \\
\hline$\left(G D P \_P P P \$\right)^{\wedge} 2$ & $0.458^{* * *}$ & $(0.137)$ & $0.306^{* * *}$ & $(0.0853)$ \\
\hline \multicolumn{5}{|l|}{ Institutional Factor } \\
\hline PolStability & $-0.112^{* *}$ & $(0.0548)$ & $-0.109 *$ & $(0.0573)$ \\
\hline \multicolumn{5}{|c|}{ Non-institutional Factor } \\
\hline GDPGrowth & -0.109 & $(0.184)$ & -0.569 & $(0.437)$ \\
\hline Inflation & 0.0696 & $(0.0581)$ & -0.0922 & $(0.158)$ \\
\hline Openness & 0.0148 & $(0.0115)$ & 0.0102 & $(0.00988)$ \\
\hline FinDepth & $-0.0610^{* *}$ & $(0.0302)$ & $-0.0585^{* *}$ & $(0.0250)$ \\
\hline Constant & \multicolumn{2}{|c|}{$47.09^{* * *}(2.679)$} & \multicolumn{2}{|c|}{$45.05 * * *(2.695)$} \\
\hline R-squared & \multicolumn{2}{|l|}{0.601} & \multicolumn{2}{|l|}{0.552} \\
\hline Observations & \multicolumn{2}{|l|}{144} & \multicolumn{2}{|l|}{149} \\
\hline F-test & \multicolumn{2}{|l|}{55.83} & \multicolumn{2}{|l|}{35.91} \\
\hline
\end{tabular}

\subsubsection{Robustness check with 5-year averages}

This subsection of robustness check utilizes panel data regressions with 5-year averages. These results are shown in Tables 6 and 7. Following the growth literature, the 5-year averages are used to smooth the cyclical elements contained in time series. Both the FE and RE estimators are listed in Table 6 below although the Hausman test suggests that the RE estimator may be inconsistent.

Finally, one concern with the panel regression is endogeneity. To check the impact of endogeneity, the paper also conducts panel data regressions with one-period lags and two-period lags. All the panel regression results support the U-shaped relationship identified previously. These robustness checks clearly demonstrate that all results are very robust after undertaking the usual tests. 


\begin{tabular}{|c|c|c|c|c|}
\hline \multirow[t]{2}{*}{ Dependent Variable } & \multicolumn{2}{|l|}{ SE ( 5 year average) } & \multicolumn{2}{|l|}{ SE (5 year average) } \\
\hline & \multicolumn{2}{|l|}{ robust FE } & \multicolumn{2}{|l|}{ robust $R E$} \\
\hline GDP_PPP\$ & $-11.59 * * *$ & (1.640) & $-8.755^{* * *}$ & (1.141) \\
\hline$\left(G D P \_P P P \$\right)^{\wedge} 2$ & $0.838^{* * *}$ & $(0.215)$ & $0.656 * * *$ & $(0.157)$ \\
\hline \multicolumn{5}{|l|}{ Institutional Factor } \\
\hline PolStability & $-0.0559 *$ & $(0.0336)$ & -0.0418 & $(0.0292)$ \\
\hline \multicolumn{5}{|c|}{ Non-institutional Factor } \\
\hline GDPGrowth & 0.0261 & $(0.0659)$ & -0.000569 & $(0.0512)$ \\
\hline Inflation & $0.0704^{* * *}$ & $(0.0221)$ & $0.0846^{* * *}$ & $(0.0185)$ \\
\hline Openness & $-0.0476 * * *$ & $(0.0148)$ & $-0.0308 * * *$ & (0.00995) \\
\hline FinDepth & -0.0136 & $(0.0119)$ & $-0.0278 * *$ & $(0.0122)$ \\
\hline Constant & $52.02 * * *$ & (3.032) & $46.89 * * *$ & (2.079) \\
\hline Observations & 558 & & 558 & \\
\hline F-test & 25.50 & & & \\
\hline
\end{tabular}

\begin{tabular}{|c|c|c|c|}
\hline \multirow[t]{2}{*}{ Dependent Variable } & SE ( 5 year average) & \multicolumn{2}{|l|}{ SE ( 5 year average) } \\
\hline & robust FE with lags & \multicolumn{2}{|l|}{ robust RE with lags } \\
\hline GDP_PPP\$(-1) & $-9.444^{* * *} \quad(1.391)$ & $-7.814 * * *$ & (0.934) \\
\hline$\left(G D P \_P P P \$(-1)\right)^{\wedge} 2$ & $0.665 * * * \quad(0.173)$ & $0.565^{* * *}$ & $(0.122)$ \\
\hline \multicolumn{4}{|l|}{ Institutional Factor } \\
\hline PolStability(-1) & $-0.00467 \quad(0.0391)$ & -0.0272 & $(0.0289)$ \\
\hline \multicolumn{4}{|c|}{ Non-institutional Factor } \\
\hline GDPGrowth(-1) & $-0.317 * * * \quad(0.0847)$ & $-0.331 * * *$ & $(0.0723)$ \\
\hline Inflation(-1) & $0.0770^{* * *} \quad(0.0191)$ & $0.0828 * * *$ & $(0.0172)$ \\
\hline Openness(-1) & $-0.0159 \quad(0.0138)$ & -0.00515 & $(0.00957)$ \\
\hline FinDepth(-1) & $-0.00410(0.0118)$ & $-0.0223^{*}$ & $(0.0123)$ \\
\hline Constant & $43.24 * * * \quad(2.817)$ & $42.13 * * *$ & (1.717) \\
\hline Observations & 414 & 414 & \\
\hline F-test & 27.36 & & \\
\hline
\end{tabular}

\begin{tabular}{|c|c|c|c|c|}
\hline \multirow[t]{2}{*}{ Dependent Variable } & \multicolumn{2}{|l|}{ SE (5 year average) } & \multicolumn{2}{|l|}{ SE (5 year average) } \\
\hline & \multicolumn{2}{|l|}{ robust FE with lags } & \multicolumn{2}{|l|}{ robust RE with lags } \\
\hline GDP_PPP\$(-2) & $-4.636 * * *$ & $(1.754)$ & $-6.294 * * *$ & (1.138) \\
\hline$\left(G D P \_P P P \$(-2)\right)^{\wedge} 2$ & $0.717 * * *$ & $(0.210)$ & $0.465 * * *$ & (0.139) \\
\hline \multicolumn{5}{|l|}{ Institutional Factor } \\
\hline PolStability(-2) & 0.0281 & (0.0459) & -0.0401 & $(0.0337)$ \\
\hline \multicolumn{5}{|c|}{ Non-institutional Factor } \\
\hline GDPGrowth(-2) & -0.104 & $(0.0853)$ & $-0.221 * * *$ & $(0.0774)$ \\
\hline Inflation(-2) & $0.0776 * * *$ & $(0.0221)$ & $0.0641 * * *$ & $(0.0150)$ \\
\hline Openness(-2) & -0.0251 & $(0.0181)$ & -0.00326 & (0.00999) \\
\hline FinDepth(-2) & -0.0105 & $(0.0130)$ & -0.0285 & $(0.0182)$ \\
\hline Constant & $33.29 * * *$ & (3.822) & $39.51^{* * *}$ & (1.837) \\
\hline Observations & 266 & & 266 & \\
\hline F-test & 6.587 & & & \\
\hline
\end{tabular}

\section{CInternational Monetary Fund. Not for Redistribution}




\subsubsection{Robustness check by controlling for the four oil-exporting countries}

This subsection aims to isolate the impact of some outliers and check the robustness of the Ushaped curve. As Figure 1 suggests, one valid concern is that the four oil-exporting countries which lie on the upward part of the curve, namely Brunei, United Arab of Emirates, Kuwait and Qatar ${ }^{18}$, may play a disproportionately large role in determining the nonlinear relationship. One way to check their role is to switch to another measurement of GDP per capita. With GDP per capita measured by constant 2010 US dollars, these four countries move to the downward part of the U curve in the Figure 2. When this measurement of level of development is used, the regression outcome in Table 9 supports the U-shaped relationship.

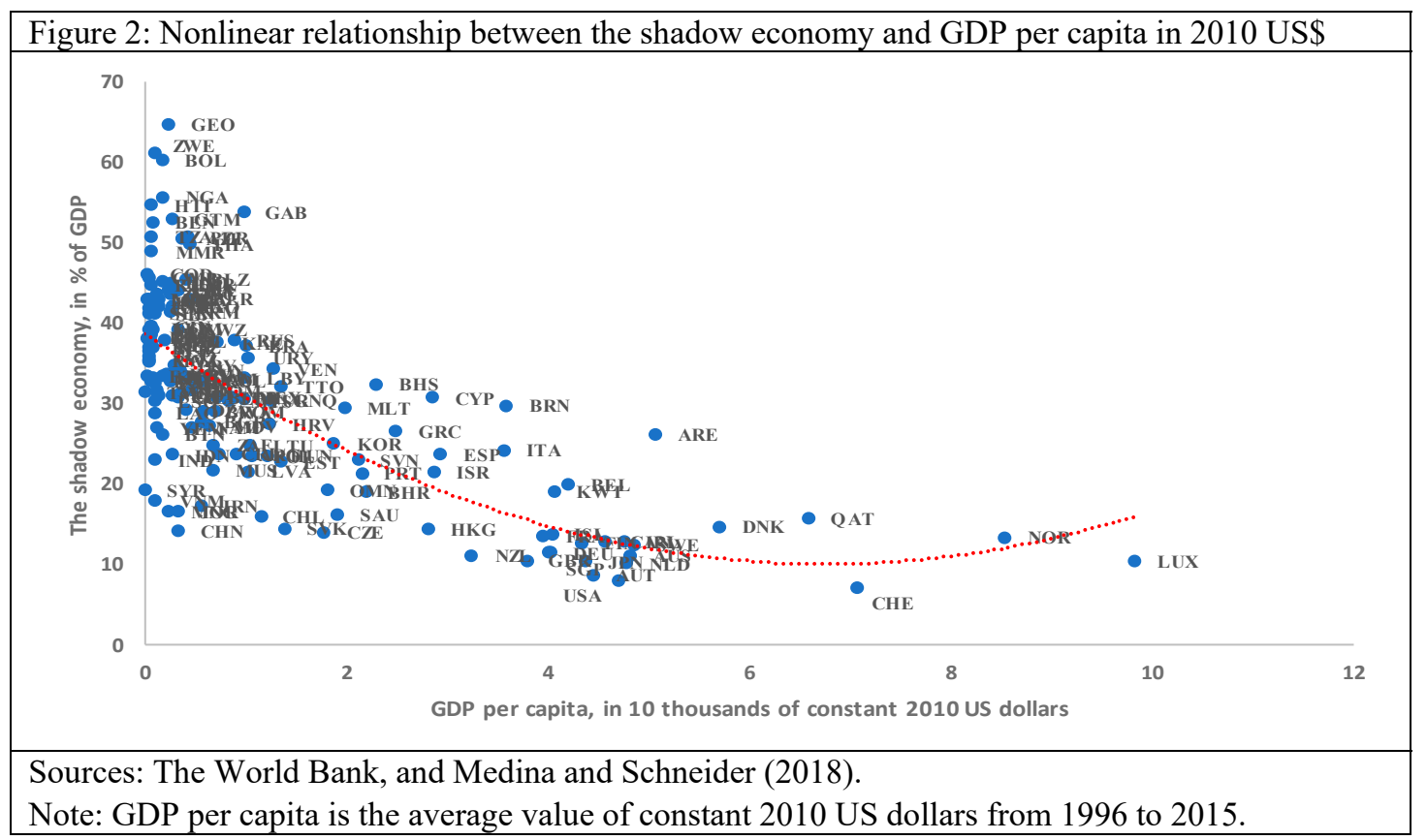

Another way to check its impact, which may be relatively convincing, is to do the regression with the same measurement while dropping the four outliers. The results are summarized below, and it is worth noting that the same $U$ curve is still identified although at a less significant level than before.

${ }^{18}$ They are highlighted with green color. 


\begin{tabular}{|c|c|c|c|c|}
\hline \multirow{2}{*}{ Dependent Variable } & \multicolumn{2}{|c|}{ SE } & \multicolumn{2}{|c|}{$\mathrm{SE}$} \\
\hline & \multicolumn{2}{|c|}{ using GDP per capital in 2010 US\$ } & \multicolumn{2}{|c|}{$\begin{array}{l}\text { using GDP per capita in PPP-based } \$ \\
\text { and dropping the four oil exporting } \\
\text { countries }\end{array}$} \\
\hline GDP_PPP\$ & & & $-5.391 * * *$ & $(1.294)$ \\
\hline$\left(G D P \_P P P \$\right)^{\wedge} 2$ & & & $0.256^{*}$ & $(0.154)$ \\
\hline GDP_2010\$ & $-5.611 * * *$ & $(1.238)$ & & \\
\hline$\left(G D P \_2010 \$\right)^{\wedge} 2$ & $0.398 * * *$ & $(0.123)$ & & \\
\hline \multicolumn{5}{|l|}{ Institutional Factor } \\
\hline PolStability & $-0.114^{*}$ & $(0.0585)$ & $-0.129 * *$ & $(0.0569)$ \\
\hline \multicolumn{5}{|c|}{ Non-institutional Factor } \\
\hline GDPGrowth & -0.362 & $(0.363)$ & -0.251 & $(0.379)$ \\
\hline Inflation & 0.115 & $(0.115)$ & 0.117 & $(0.112)$ \\
\hline Openness & 0.00458 & (0.0109) & 0.0205 & $(0.0124)$ \\
\hline FinDepth & $-0.0479 *$ & $(0.0279)$ & -0.0452 & $(0.0282)$ \\
\hline Constant & $43.82^{* * *}$ & (2.689) & $44.48^{* * *}$ & (2.603) \\
\hline R-squared & 0.569 & & 0.585 & \\
\hline Observations & 152 & & 148 & \\
\hline F-test & 64.94 & & 64.94 & \\
\hline
\end{tabular}

\subsection{More Discussions on Labor Market and Policy Implications}

One view on the shadow economy is that labor market rigidity makes the job search and matching process lengthy and costly, thus discouraging firms to register newly hired workers with the authorities or to stay formal and causing workers, especially migrant workers, to be less interested in the formal jobs in order to earn income easier and earlier. Thus, it is important to control for the institutional effect of labor market rigidities when examining the determinants of the shadow economy. In response, the paper uses the indicator of labor market flexibility from the World Economic Forum Global Competitiveness Index (GCI) to control for the institutional factors of the labor market. The indicator is on a scale of 1-7 with high values meaning more flexibility. The results are summarized in the table below. Labor market flexibility helps reduce the size of the shadow economy in the long run although not significantly. Meanwhile, the coefficient of squared GDP per capita remains significant to support the U-shaped curve. 


\begin{tabular}{|lc|}
\hline \multicolumn{2}{|l|}{ Table 10: Robustness check VIII: the average of 1996-2015 } \\
\hline \multicolumn{2}{|c|}{ Dependent Variable } \\
\cline { 2 - 2 } GDP_PPP\$ & With labor market indicator \\
\cline { 2 - 2 } (GDP_PPP\$)^ & $-6.086^{* * *}(1.310)$ \\
Institutional Factor & $0.413^{* * *}(0.124)$ \\
PolStability & $-0.125^{* *}(0.0614)$ \\
Non-institutional Factor & \\
GDPGrowth & $-0.594(0.573)$ \\
Inflation & $0.0480(0.128)$ \\
Openness & $0.0179(0.0121)$ \\
FinDepth & $-0.0544^{*}(0.0292)$ \\
LabMarket & $-0.205(1.606)$ \\
& \\
Constant & $47.81^{* * *}(7.582)$ \\
& \\
\hline R-squared & 0.578 \\
Observations & 139 \\
F-test & 34.75 \\
\hline Notes: Standard errors in parentheses; $* \mathrm{p}<0.10, * * \mathrm{p}<0.05, * * * \mathrm{p}<0.01$. \\
\hline
\end{tabular}

It is arguable that not only institutional factors but also the labor force composition of the market can exert some influence on the relative size of the shadow economy. For example, Goldin (1994) finds the U-shaped curve between female labor participation and economic development. The female participation declines initially with economic development and then picks up after a turning point. If the estimated trend in Goldin (1994) is true, it is reasonable to predict that more male individuals tend to work informally with economic development. It can be a good topic for further investigation with data availability.

To set out appropriate and effective measures to tackle the associated issues, it is necessary first to have a comprehensive and updated view on the role of the shadow economy on economic growth and social welfare. ${ }^{19}$ First, the existence of the shadow economy poses a severe threat to fiscal revenue collection and thus undermines the government's ability to provide adequate public goods and services. Second, empirical evidence shows that firms in the shadow economy are smaller and less productive than those in the formal sector. Third, the authorities have very limited access to information related to the shadow economy, which weakens their efforts to implement economic monitoring and management. Fourth, the shadow economy keeps evolving and adapts to new developments and thus it is crucial for the policymakers to update their knowledge on the shadow economy on a regular basis. However, the shadow economy does play a positive role in some aspects by improving worker's welfare. For example, the informal sector supports worker's ability to make a living by providing temporary and low-paid jobs when the economy does not have a well-established social safety net. Also, the informal sector helps the economy to maintain an untapped reservoir of labor supply. When a positive shock to demand emerges, the economy can quickly grab the opportunity to step up production by utilizing extra labor supply in the shadow economy.

${ }^{19}$ La Porta and Shleifer $(2008,2014)$ have good summaries about the views of the role of the shadow economy. 
Besides the mixed views above on the shadow economy, the paper's finding provides another reason for policymakers to be cautious when handling issues related to the shadow economy. Just as the paper reveals, if the long-run trend of the shadow economy can be reversed with economic development, then it is key to be aware of the current state of the economy and remain alert to the policy effectiveness. If the economy is less-developed or experiences a catch-up phase, its shadow economy is expected to go through a downsizing process. In this period, the authorities can harness the trend to attract more firms and workers out of the shadow economy by promoting financial development, containing inflation, stabilizing the political situation, and expanding educational spending. By contrast, when the economy has reached the threshold of GDP per capita and starts to show the positive relationship between GDP per capita and the shadow economy, the authorities should put additional efforts to make working in the formal sector more beneficial, for example by reducing labor market rigidities to improve market efficiency and simplifying tax compliance procedures with recent technology innovations.

It should be clear, from our results that show the importance of the level of economic development, that taking harsh measures with a view to dramatically reducing or even to eradicating the shadow economy is not a first-best solution. The appropriateness of the policy depends on the level of economic development. This section sets out the following policy recommendations for consideration:

The authorities should strengthen their capacity in data collecting and processing. In order to assess the current stage of the relationship between the shadow economy and level of development, it is crucial for the policy makers to exploit all available data sources, especially given the rapid growth of the digital economy in recent years, and to call for the relevant government agencies to work collectively to cross check the data quality. The authorities should be able to measure the impact of its policy in a relatively accurate way and thus to keep adjusting its policy to achieve the better outcomes.

The authorities should streamline the administrative procedures to reduce the compliance costs of firms and households and make public goods and services more accessible by taking advantage of technology innovations. The growing digital economy provides new advantages and convenience for workers to stay in the informal sector. In response, the associated government agencies should revise their policy measures to create a business-friendly environment and ensure that firms and workers can obtain these advantages and stay or move to the formal sector.

The authorities should keep educating people, not only to improve their human capital but also to teach them about the role of the shadow economy and promote healthy social norms to positively influence people's economic behavior. It is important to advise all firms and households on the merits and risks of the shadow economy and ensure that there is a positive attitude toward formal jobs and an understanding of the importance of transparency for economic monitoring and policy designing. 


\section{CONCLusion}

In this paper, we reveal a long-run U-shaped relationship between GDP per capita and the size of the shadow economy with a dataset of 158 countries. Further, this paper examines the possible long-run determinants of GDP per capita and finds that the share of the population with a bachelor's degree or above plays a vital role in promoting average productivity, which is consistent with existing literature.

The U-shaped pattern between the shadow economy and GDP per capita is worth further investigation. One possible direction is whether the non-monotonic relationship before and after the threshold are symmetric. Although this paper identifies a long-run nonlinearity in the shadow economy using the quadratic regression equation, it is possible for the relationship between GDP per capita and the size of the shadow economy to be asymmetric. One possible scenario could be that the productivity increase of the shadow economy may accelerate when the country's level of development exceeds a certain stage, resulting from industrial advancement in the formal sector and technological innovation. 


\section{REFERENCES}

Acemoglu, Daron, 2002. "Technical Change, Inequality, and the Labor Market," Journal of Economic Literature, 40(1): 7-72.

Adair, Philippe, 2017. "Non-Observed Economy vs. the Shadow Economy in the EU: The Accuracy of Measurements Methods and Estimates revisited," 4th OBEGEF Interdisciplinary Insights on Fraud and Corruption; Nov. 2017, Porto, Portugal.

Buehn, Andreas and Mohammad Reza Farzanegan, 2013. "Impact of Education on the Shadow Economy: Institutions Matter," Economics Bulletin, AccessEcon, vol. 33(3), pages 2052-2063.

Barro, Robert J., 2013. "Inflation and Economic Growth," Annals of Economics and Finance, Society for AEF, vol. 14(1), pages 121-144, May.

Medina, Leandro and Friedrich Schneider, 2018. "Shadow Economies Around the World: What Did We Learn Over the Last 20 Years?" the IMF working Paper.

Elbahnasawy, Nasr G. Michael A. Ellis and Assandé Désiré Adom, 2016. "Political Instability and the Informal Economy," World Development, Elsevier, vol. 85(C), pages 31-42.

Elgin, Ceyhun and Ferda Erturk, 2016. "Is Informality a Barrier to Convergence?" Economics Bulletin, AccessEcon, vol. 36(4), pages 2556-2568.

Elgin, Ceyhun and Ferda Erturk, 2018. "Informal economies around the world: measures, determinants and consequences," Eurasian Economic Review 1-17, 2018.

Elgin, Ceyhun and Mario-Solis Garcia, 2012. "Public Trust, Taxes and the Informal Sector,s" Boğaziçi Journal Review of Social, Economic and Administrative Studies, Vol. 26 (1), pp. $27-$ 44.

Elgin, Ceyhun and Serdar Birinci, 2016. "Growth and informality: A comprehensive panel data analysis," Journal of Applied Economics, issue 19, p.271-292.

Elgin, Ceyhun and Oguz Oztunali, 2012. "Shadow Economies around the World: Model Based Estimates," Working Papers 2012/05, Bogazici University, Department of Economics.

Feld, Lars P. and C. Larsen, 2009. "Undeclared Work in Germany 2001- 2007 Impact of Deterrence, Tax Policy, and Social Norms: An Analysis Based on Survey Data," Springer, Berlin.

Feld, Lars P. and Friedrich Schneider, 2010. "Survey on the Shadow Economy and Undeclared Earnings in OECD Countries," German Economic Review, 11(2), 109-149. 
Friedman, Eric and Simon Johnson and Daniel Kaufmann and Pablo Zoido-Lobaton, 2000.

"Dodging the grabbing hand: the determinants of unofficial activity in 69 countries," Journal of Public Economics, Elsevier, vol. 76(3), pages 459-493.

Gerxhani, Klarita, 2003. "The informal sector in developed and less-developed countries: A literature survey," Public Choice, 114/3-4, pp 295-318.

Goldin, Claudia, 1994. "The U-Shaped Female Labor Force Function in Economic Development and Economic History," NBER Working Papers 4707, NBER, Inc.

IMF, 2017. "Seeking Sustainable Growth: Short-Term Recovery, Long-Term Challenges," World Economic Outlook, October.

Kirchgaessner, Gebhard, 2016. "On Estimation the Size of the Shadow Economy," German Economic Review 18/1, pp. 99-111.

Lewis, W. Arthur, 1954. "Economic Development with Unlimited Supplies of Labor," Manchester School of Economic and Social Studies 22(2): 139-91.

Medina, Leandro and Friedrich Schneider, 2017. "Shadow Economies around the World: What did We Learn Over the Last 20 Years?” Discussion Paper, University of Linz, Linz

La Porta, Rafael and Andrei Shleifer, 2008. "The Unofficial Economy and Economic Development," Brookings Papers on Economic Activity, Economic Studies Program, The Brookings Institution, vol. 39-2 (Fall), pages 275-363.

La Porta, Rafael and Andrei Shleifer, 2014. "Informality and Development," Journal of Economic Perspectives, American Economic Association, vol. 28(3), pages 109-26.

Schneider, Friedrich and Dominik H. Enste, 2000. "Shadow Economies: Size, Causes, and Consequences," Journal of Economic Literature, 38 (1): 77-114.

Schneider, Friedrich, 2014. "The Shadow Economy: An Essay,” Manuscript.

Schneider, Friedrich and Andreas Buehn, 2017. "Estimating a Shadow Economy: Results, Methods, Problems, and Open Questions," Open Economics 2017 vol(1), pp. 1-29.

Williams, Colin C. and Friedrich Schneider, 2016. "Measuring the Global Shadow Economy: The Prevalence of Informal Work and Labor,” Edward Elgar Publishing, UK. 


\section{APPENDIX}

\begin{tabular}{|c|c|c|c|c|c|}
\hline Albania & ALB & Gabon & GAB & Netherlands, The & NLD \\
\hline Algeria & DZA & Gambia, The & GMB & New Zealand & NZL \\
\hline Angola & AGO & Georgia & GEO & Nicaragua & NIC \\
\hline Argentina & ARG & Germany & DEU & Niger & NER \\
\hline Armenia & ARM & Ghana & GHA & Nigeria & NGA \\
\hline Australia & AUS & Greece & GRC & Norway & NOR \\
\hline Austria & AUT & Guatemala & GTM & Oman & OMN \\
\hline Azerbaijan & AZE & Guinea & GIN & Pakistan & PAK \\
\hline Bahamas, The & BHS & Guinea-Bissau & GNB & Papua New Guinea & PNG \\
\hline Bahrain & $\mathrm{BHR}$ & Guyana & GUY & Paraguay & PRY \\
\hline Bangladesh & BGD & Haiti & $\mathrm{HTI}$ & Peru & PER \\
\hline Belarus & BLR & Honduras & HND & Philippines & $\mathrm{PHL}$ \\
\hline Belgium & BEL & Hong Kong SAR, China & HKG & Poland & POL \\
\hline Belize & BLZ & Hungary & HUN & Portugal & PRT \\
\hline Benin & BEN & Iceland & ISL & Qatar & QAT \\
\hline Bhutan & BTN & India & IND & Romania & ROM \\
\hline Bolivia & $\mathrm{BOL}$ & Indonesia & IDN & Russian Federation & RUS \\
\hline Bosnia and Herzegovina & $\mathrm{BIH}$ & Iran, Islam Rep. & IRN & Rwanda & RWA \\
\hline Botswana & BWA & Ireland & IRL & Saudi Arabia & SAU \\
\hline Brazil & BRA & Israel & ISR & Senegal & SEN \\
\hline Brunei Darussalam & BRN & Italy & ITA & Sierra Leone & SLE \\
\hline Bulgaria & BGR & Jamaica & JAM & Singapore & SGP \\
\hline Burkina Faso & BFA & Japan & $J P N$ & Slovak Republic & SVK \\
\hline Burundi & $\mathrm{BDI}$ & Jordan & JOR & Slovenia & SVN \\
\hline Cabo Verde & CPV & Kazakhstan & KAZ & Solomon Islands & SLB \\
\hline Cambodia & KHM & Kenya & KEN & South Africa & ZAF \\
\hline Cameroon & CMR & Korea, Rep. & KOR & Spain & ESP \\
\hline Canada & CAN & Kuwait & KWT & Sri Lanka & LKA \\
\hline Central African Republic & CAF & Kyrgyz Republic & KGZ & Suriname & SUR \\
\hline Chad & $\mathrm{TCD}$ & Laos & LAO & Swaziland & SWZ \\
\hline Chile & $\mathrm{CHL}$ & Latvia & LVA & Sweden & SWE \\
\hline China & $\mathrm{CHN}$ & Lebanon & LBN & Switzerland & $\mathrm{CHE}$ \\
\hline Colombia & $\mathrm{COL}$ & Lesotho & LSO & Syrian Arab. Rep. & SYR \\
\hline Comoros & COM & Liberia & LBR & Taiwan & TWN \\
\hline Congo, Dem. Rep. & COD & Libya & LBY & Tajikistan & TJK \\
\hline Congo, Rep. & COG & Lithuania & LTU & Tanzania & TZA \\
\hline Costa Rica & CRI & Luxembourg & LUX & Thailand & THA \\
\hline Côte d'Ivoire & CIV & Madagascar & MDG & Togo & TGO \\
\hline Croatia & HRV & Malawi & MWI & Trinidad and Tobago & тто \\
\hline Cyprus & CYP & Malaysia & MYS & Tunisia & TUN \\
\hline Czech Republic & CZE & Maldives & MDV & Turkey & TUR \\
\hline Denmark & DNK & Mali & MLI & Uganda & UGA \\
\hline Dominican Republic & DOM & Malta & MLT & Ukraine & UKR \\
\hline Ecuador & ECU & Mauritania & MRT & United Arab Emirates & ARE \\
\hline Egypt, Arab. Rep. & EGY & Mauritius & MUS & United Kingdom & GBR \\
\hline El Salvador & SLV & Mexico & MEX & United States & USA \\
\hline Equatorial Guinea & GNQ & Moldova & MDA & Uruguay & URY \\
\hline Eritrea & ERI & Mongolia & MNG & Venezuela, RB & VEN \\
\hline Estonia & EST & Morocco & MAR & Vietnam & VNM \\
\hline Ethiopia & ETH & Mozambique & $\mathrm{MOZ}$ & Yemen, Rep. & YEM \\
\hline Fiji & FJI & Myanmar & MMR & Zambia & ZMB \\
\hline Finland & FIN & Namibia & NAM & Zimbabwe & ZWE \\
\hline France & FRA & Nepal & NPL & & \\
\hline
\end{tabular}




\begin{tabular}{|c|c|c|c|c|c|c|c|c|c|c|c|c|}
\hline & & SE & SE2 & GDP_PPP\$ & GDP_2010\$ & PolStability & GDPGrowth & Inflation & Openness & FinDepth & TaxBurden & LabMarket \\
\hline SE & $\begin{array}{l}\text { The size of the Shadow Economy } \\
\text { in \% of GDP, from Medina and } \\
\text { Schneider (2018) }\end{array}$ & 1 & & & & & & & & & & \\
\hline SE2 & $\begin{array}{l}\text { The size of the Shadow Economy } \\
\text { in \% of GDP, from Elgin and } \\
\text { Oztunal (2012) }\end{array}$ & $0.945^{* * *}$ & 1 & & & & & & & & & \\
\hline GDP_PPP\$ & $\begin{array}{l}\text { GDP per capita, in } 10 \text { thousands } \\
\text { of PPP-based constant US\$ }\end{array}$ & $-0.670^{* * *}$ & $-0.676^{* * *}$ & 1 & & & & & & & & \\
\hline GDP_2010\$ & $\begin{array}{l}\text { GDP per capita, in } 10 \text { thousands } \\
\text { of } 2010 \text {-based constant US\$ }\end{array}$ & $-0.682^{* * *}$ & $-0.683^{* * *}$ & $0.901^{* * *}$ & 1 & & & & & & & \\
\hline PolStability & $\begin{array}{l}\text { Index of Political Stability and } \\
\text { absence of Violence and } \\
\text { Terrorism, from the WGI } \\
\text { database }\end{array}$ & $-0.608 * * *$ & $-0.556 * * *$ & $0.583^{* * *}$ & $0.618^{* * *}$ & 1 & & & & & & \\
\hline GDPGrowth & Growth of GDP per capita, in \% & $0.147^{* * *}$ & $0.224^{* * *}$ & $-0.239 * * *$ & $-0.242^{* * *}$ & $-0.0900 * *$ & 1 & & & & & \\
\hline Inflation & CPI Inflation, in \% & $0.254^{* * *}$ & $0.239 * * *$ & $-0.303^{* * *}$ & $-0.339 * * *$ & $-0.318^{* * *}$ & $0.146^{* * *}$ & 1 & & & & \\
\hline Openness & $\begin{array}{l}\text { Trade openness, the sum of } \\
\text { exports and imports of goods and } \\
\text { services in \% of GDP }\end{array}$ & $-0.308 * * *$ & $-0.315^{* * *}$ & $0.427^{* * *}$ & $0.345^{* * *}$ & $0.394^{* * *}$ & 0.0295 & $-0.155^{* * *}$ & 1 & & & \\
\hline FinDepth & $\begin{array}{l}\text { Credit to the private sector, in \% } \\
\text { of GDP }\end{array}$ & $-0.562 * * *$ & $-0.591 * * *$ & $0.536^{* * *}$ & $0.630 * * *$ & $0.483 * * *$ & $-0.236^{* * *}$ & $-0.340 * * *$ & $0.278^{* * *}$ & 1 & & \\
\hline TaxBurden & $\begin{array}{l}\text { Tax and mandatory contributions } \\
\text { as a share of commercial profit, } \\
\text { in \% }\end{array}$ & $0.207^{* * *}$ & $0.200 * * *$ & $-0.251^{* * *}$ & $-0.177^{* * *}$ & $-0.189 * * *$ & -0.0216 & 0.0693* & $-0.222 * * *$ & $-0.200 * * *$ & 1 & \\
\hline CapStock & $\begin{array}{l}\text { Capital stock in billions of constant } \\
2011 \text { international dollars }\end{array}$ & -0.0568 & -0.0223 & -0.0620 & -0.0379 & $-0.100 * *$ & $0.0750^{*}$ & 0.0532 & -0.0381 & 0.00406 & -0.0469 & 1 \\
\hline LabMarket & $\begin{array}{l}\text { The indicator measures the } \\
\text { flexibility of labor market with a } \\
\text { scale of } 1-7 \text { (best) }\end{array}$ & $-0.205^{* * *}$ & $-0.225 * * *$ & $0.311^{* * *}$ & $0.234^{* * *}$ & $0.243^{* * *}$ & -0.00701 & $-0.180^{* * *}$ & $0.397^{* * *}$ & $0.246 * * *$ & $-0.207^{* * *}$ & $-0.223^{* * *}$ \\
\hline \multicolumn{13}{|c|}{$\begin{array}{l}\text { Notes: } \\
\text { The correlation matrix is calculated with } 958 \text { annual observations. } \\
\text { Educational variables are not included because of their small numbers of observations. } \\
\text { In addition, } * \mathrm{p}<0.10, * * \mathrm{p}<0.05, * * * \mathrm{p}<0.01 \text {. } \\
\text { Sources: Medina and Schneider (2018), Elgin and Oztunal(2012), WDI, WGI, IMF ICSD and GCI. }\end{array}$} \\
\hline
\end{tabular}

\section{CInternational Monetary Fund. Not for Redistribution}




\begin{tabular}{|c|c|c|c|c|c|c|}
\hline Variable & Description & Mean & Std. Dev. & Min & Max & Observations \\
\hline SE & $\begin{array}{l}\text { The size of the Shadow Economy in \% of GDP, } \\
\text { from Medina and Schneider (2018) }\end{array}$ & 31.016 & 12.788 & 6.160 & 71.332 & 3,160 \\
\hline SE2 & $\begin{array}{l}\text { The size of the Shadow Economy in \% of GDP, } \\
\text { from Elgin and Oztunal (2012) }\end{array}$ & 31.536 & 12.192 & 7.924 & 67.801 & 2,888 \\
\hline GDP_PPP\$ & $\begin{array}{l}\text { GDP per capita, in } 10 \text { thousands of PPP-based } \\
\text { constant US\$ }\end{array}$ & 1.667 & 1.960 & 0.026 & 12.935 & 3,099 \\
\hline GDP_2010\$ & $\begin{array}{l}\text { GDP per capita, in } 10 \text { thousands of 2010-based } \\
\text { constant US\$ }\end{array}$ & 1.280 & 1.831 & 0.012 & 11.197 & 3,099 \\
\hline PolStability & $\begin{array}{l}\text { Index of Political Stability and absence of } \\
\text { Violence and Terrorism, from the WGI } \\
\text { database }\end{array}$ & 48.39 & 18.49 & 0.35 & 85.20 & 2,652 \\
\hline GDPGrowth & Growth of GDP per capita, in \% & 2.55 & 5.90 & -62.23 & 140.50 & 3,107 \\
\hline Inflation & CPI Inflation, in \% & 7.24 & 12.29 & -4.01 & 198.52 & 2,987 \\
\hline Openness & $\begin{array}{l}\text { Trade openness, the sum of exports and } \\
\text { imports of goods and services in \% of GDP }\end{array}$ & 88.11 & 55.44 & 0.17 & 531.74 & 3,045 \\
\hline FinDepth & Credit to the private sector, in $\%$ of GDP & 46.93 & 45.16 & 0.49 & 312.12 & 2,932 \\
\hline TaxBurden & $\begin{array}{l}\text { Tax and mandatory contributions as a share of } \\
\text { commercial profit, in \% }\end{array}$ & 48.08 & 39.79 & 8.00 & 339.10 & 1,607 \\
\hline College & $\begin{array}{l}\text { people completing the college, in } \% \text { of the } \\
\text { population of age of } 25+\end{array}$ & 17.22 & 9.21 & 0.00 & 36.95 & 165 \\
\hline HighSch & $\begin{array}{l}\text { people completing the high school, in } \% \text { of the } \\
\text { population of age of } 25+\end{array}$ & 38.81 & 18.41 & 0.96 & 82.46 & 164 \\
\hline PriSch & $\begin{array}{l}\text { people completing the primary school, in } \% \text { of } \\
\text { the population of age of } 25+\end{array}$ & 31.50 & 14.86 & 3.02 & 78.77 & 571 \\
\hline CapStock & $\begin{array}{l}\text { Capital stock in billions of constant } 2011 \\
\text { international dollars }\end{array}$ & 4839.89 & 1762.20 & 218 & 8543 & 3,010 \\
\hline LabMarket & $\begin{array}{l}\text { The indicator measures the flexibility of labor } \\
\text { market with a scale of 1-7(best) }\end{array}$ & 4.51 & 0.62 & 2.41 & 6.39 & 1,301 \\
\hline
\end{tabular}

\section{CInternational Monetary Fund. Not for Redistribution}




\begin{tabular}{|c|c|c|c|c|c|}
\hline \multirow[t]{2}{*}{ Advanced Economies (AEs) } & \multicolumn{2}{|c|}{ Non-Advanced Economies (non-AEs) } & \multirow[t]{2}{*}{$\underline{\text { High-income Countries (HICs) }}$} & \multicolumn{2}{|c|}{ Non-high-income Countries (Non-HICs) } \\
\hline & & & & Middle-income Countries (MICs) & \\
\hline Australia & Albania & Kuwait & Australia & $\overline{\text { Albania }}$ & Peru \\
\hline Austria & Algeria & Kyrgyz Republic & Austria & Algeria & Philippines \\
\hline Belgium & Angola & Laos & Bahamas, The & Angola & Romania \\
\hline Canada & Argentina & Lebanon & Bahrain & Argentina & Russian Federation \\
\hline Cyprus & Armenia & Lesotho & Belgium & Armenia & Solomon Islands \\
\hline Czech Republic & Azerbaijan & Liberia & Brunei Darussalam & Azerbaijan & South Africa \\
\hline Denmark & Bahamas, The & Libya & Canada & Bangladesh & Sri Lanka \\
\hline Estonia & Bahrain & Madagascar & Chile & Belarus & Suriname \\
\hline Finland & Bangladesh & Malawi & Croatia & Belize & Swaziland \\
\hline France & Belarus & Malaysia & Cyprus & Bhutan & Syrian Arab. Rep. \\
\hline Germany & Belize & Maldives & Czech Republic & Bolivia & Tajikistan \\
\hline Greece & Benin & Mali & Denmark & Bosnia and Herzegovina & Thailand \\
\hline Iceland & Bhutan & Mauritania & Estonia & Botswana & Tunisia \\
\hline Ireland & Bolivia & Mauritius & Finland & Brazil & Turkey \\
\hline Israel & Bosnia and Herzegovina & Mexico & France & Bulgaria & Ukraine \\
\hline Italy & Botswana & Moldova & Germany & Cabo Verde & Venezuela, RB \\
\hline Japan & Brazil & Mongolia & Greece & Cambodia & Vietnam \\
\hline Korea, Rep. & Brunei Darussalam & Morocco & Hong Kong SAR, China & Cameroon & Yemen, Rep. \\
\hline Latvia & Bulgaria & Mozambique & Hungary & China & Zambia \\
\hline Lithuania & Burkina Faso & Myanmar & Iceland & Colombia & \\
\hline Luxembourg & Burundi & Namibia & Ireland & Congo, Rep. & \\
\hline Malta & Cabo Verde & Nepal & Israel & Costa Rica & Low-income Countries (LCS) \\
\hline Netherlands, The & Cambodia & Nicaragua & Italy & Côte d'Ivoire & Benin \\
\hline New Zealand & Cameroon & Niger & Japan & Dominican Republic & Burkina Faso \\
\hline Norway & Central African Republic & Nigeria & Korea, Rep. & Ecuador & Burundi \\
\hline Portugal & Chad & Oman & Kuwait & Egypt, Arab. Rep. & Central African Republic \\
\hline Singapore & Chile & Pakistan & Latvia & El Salvador & Chad \\
\hline Slovak Republic & China & Papua New Guinea & Lithuania & Equatorial Guinea & Comoros \\
\hline Slovenia & Colombia & Paraguay & Luxembourg & Fiji & Congo, Dem. Rep. \\
\hline Spain & Comoros & Peru & Malta & Gabon & Eritrea \\
\hline Sweden & Congo, Dem. Rep. & Philippines & Netherlands, The & Georgia & Ethiopia \\
\hline Switzerland & Congo, Rep. & Poland & New Zealand & Ghana & Gambia, The \\
\hline United Kingdom & Costa Rica & Qatar & Norway & Guatemala & Guinea \\
\hline \multirow{29}{*}{ United States } & Côte d'Ivoire & Romania & Oman & Guyana & Guinea-Bissau \\
\hline & Croatia & Russian Federation & Poland & Honduras & Haiti \\
\hline & Dominican Republic & Rwanda & Portugal & India & Liberia \\
\hline & Ecuador & Saudi Arabia & Qatar & Indonesia & Madagascar \\
\hline & Egypt, Arab. Rep. & Senegal & Saudi Arabia & Iran, Islam Rep. & Malawi \\
\hline & El Salvador & Sierra Leone & Singapore & Jamaica & Mali \\
\hline & Equatorial Guinea & Solomon Islands & Slovak Republic & Jordan & Mozambique \\
\hline & Eritrea & South Africa & Slovenia & Kazakhstan & Nepal \\
\hline & Ethiopia & Sri Lanka & Spain & Kenya & Niger \\
\hline & Fiji & Suriname & Sweden & Kyrgyz Republic & Rwanda \\
\hline & Gabon & Swaziland & Switzerland & Laos & Senegal \\
\hline & Gambia, The & Syrian Arab. Rep. & Taiwan & Lebanon & Sierra Leone \\
\hline & Georgia & Taiwan & Trinidad and Tobago & Lesotho & Tanzania \\
\hline & Ghana & Tajikistan & United Arab Emirates & Libya & Togo \\
\hline & Guatemala & Tanzania & United Kingdom & Malaysia & Uganda \\
\hline & Guinea & Thailand & United States & Maldives & Zimbabwe \\
\hline & Guinea-Bissau & Togo & Uruguay & Mauritania & \\
\hline & Guyana & Trinidad and Tobago & & Mauritius & \\
\hline & Haiti & Tunisia & & Mexico & \\
\hline & Honduras & Turkey & & Moldova & \\
\hline & Hong Kong SAR, China & Uganda & & Mongolia & \\
\hline & Hungary & Ukraine & & Morocco & \\
\hline & India & United Arab Emirates & & Myanmar & \\
\hline & Indonesia & Uruguay & & Namibia & \\
\hline & Iran, Islam Rep. & Venezuela, RB & & Nicaragua & \\
\hline & Jamaica & Vietnam & & Nigeria & \\
\hline & Jordan & Yemen, Rep. & & Pakistan & \\
\hline & Kazakhstan & Zambia & & Papua New Guinea & \\
\hline & Kenya & Zimbabwe & & Paraguay & \\
\hline $\begin{array}{l}\text { Notes: } \\
\text { 1/ The country group } \\
\text { 2/ The income countr } \\
\text { Sources: IMF WEO a }\end{array}$ & $\begin{array}{l}\text { Advanced Ec } \\
\text { groups are bas } \\
\text { ad the World B }\end{array}$ & $\begin{array}{l}\text { es }(\mathrm{AE}) \text { is cor } \\
\text { he World Bar }\end{array}$ & $\begin{array}{l}\text { ith IMF (2017). } \\
\text { ion. }\end{array}$ & & \\
\hline
\end{tabular}

